\title{
Meningkatkan Kemampuan Menghitung dengan Pendekatan Kontekstual Terhadap Hasil Belajar Peserta Didik Tugasku Sehari-Hari Kelas II SD Labschool STKIP Muhammadiyah Sorong
}

\author{
Alman \\ Program Studi Pendidikan Guru Sekolah Dasar \\ Universitas Pendidikan Muhammadiyah Sorong \\ Almankuntara87@gmail.com
}

\begin{abstract}
Abstrak : Penelitian ini bertujuan untuk mengetahui peningkatan pendekatan kontekstual terhadap hasil belajar peserta didik kelas II SD Labschool STKIP Muhammadiyah Sorong. Penelitian ini merupakan penelitian tindakan kelas. Variabel penelitian ini terdiri dari variabel bebas yaitu pendekatan kontekstual dan variabel terikat yaitu hasil belajar peserta didik. Populasi dalam penelitian ini adalah peserta didik kelas II SD Labschool STKIP Muhammadiyah Sorong semester I tahun ajaran 2019/2020 yangberjumlah 8peserta didik.Hasil penelitian menunjukkan bahwa ada peningkatan hasil belajar belajar Peserta didik. Hasil belajar saat pratindakan, ratarata kelas adalah 65,76 untuk ketuntasan ada 3 peserta didik atau $40 \%$ dan belum tuntas ada 5 peserta didik atau $60 \%$. Hasil ini belum memenuhi KKM yaitu 70,00. Pada siklus I diperoleh peningkatan hasil rata-rata kelas71,92, ketuntasan ada 5peserta didikatau $60 \%$ dan belum tuntas ada 3 peserta didik atau $40 \%$ berarti ada kenaikan nilai rata-rata pra tindakan ke siklus I sebesar 6,16, sedangkan siklus II hasilnya mengalami kenaikan lagi yaitu rata-rata kelas meningkat menjadi 76,90 dan ketuntasan ada 7 peserta didik atau 85,71\% dan belum tuntas ada 1peserta didik atau 14,29\%, dengan demikian ada kenaikan rata-rata dari siklus I ke siklus II sebesar 4,98. Selain itu kemampuan peserta didik dalam mengikuti pembelajaran juga meningkat. Hal ini ditandai dengan meningkatnya kemampuan peserta didik dalam bertanya, menjawab pertanyaan dan mengemukakan pendapat.
\end{abstract}

Kata Kunci: Pendekatan Kontekstual, hasil belajar, Labschool STKIP Muhammadiyah

\begin{abstract}
This study aims to determine the improvement of contextual approaches to student learning outcomes of Class II Labschool Elementary School STKIP Muhammadiyah Sorong. This research is a class action research. This research is the second grade students of Labschool Primary School STKIP Muhammadiyah Sorong Semester I in the academic year 2019/2020 with a total of 8 students. The results of the study indicate that there is an increase in learning outcomes of students. Learning outcomes during pre-action, the average class is 65.76 for completeness there are 3 students or $40 \%$ and incomplete there are 5 students or $60 \%$. These results do not meet the KKM which is 70.00 . In cycle I obtained an increase in the average grade of 71.92 , completeness there were 5 students or $60 \%$ and incomplete there were 3 students or $40 \%$ means there was an increase in the average value of pre-action to cycle I amounted to 6.16, while the second cycle the result has increased again namely the class average increased to 76.90 and completeness there are 7 students or $85.71 \%$ and not complete there are 1 students or $14.29 \%$, thus there is an increase in the average from cycle I to cycle II of 4.98 . Besides the ability of students to participate in learning also increased. This is marked by an increase in the ability of students to ask questions, answer questions and raise opinions.
\end{abstract}

Keywords: Contextual Approach, learning outcomes 


\section{Pendahuluan}

Pelaksanaan kegiatan pendidikan di sekolah, hendaknya peserta didik dibekali dengan kemampuan berpikir logis, analisis, kritis dan kreatif agar menjadi sumberdaya manusia yang tangguh dan bisa bersaing di era globalisasi. Pengembangan sikap berpikir logis, analisis, dan kritis dapat dilakukan dengan cara mengaikatkan materi pembelajaran dengan pengalaman yang dialami peserta didik dan dengan memperdalam latihan pemecahan masalah. Dalam proses pembelajaran maupun pemecahan masalah, peserta didik dapat memperoleh pengalaman yang bermakna dimana menggunakan pengetahuan serta keterampilan yang sudah dimiliki.

Pendekatan pembelajaran yang tepat untuk memfasilitasi peserta didik untuk melatih kemampuan pemecahan masalah adalah pendekatan kontekstual.Pendekatan pembelajaran yang dapat melatih pemecahan masalah untuk peserta didik dan berkaitan dengan dunia nyata adalah pendekatan kontekstual.Pembelajaran kontekstual merupakan suatu konsepsi yang membantu guru mengaitkan konten pelajaran dengan situasi dunia nyata dan memotivasi peserta didik membuat hubungan antara pengetahuan dan penerapannya dalam kehidupan mereka (Trianto, 2011: 104). Dalam pembelajaran kontekstual ini peserta didik diharapkan dapat mengambil manfaat dari apa yang dipelajari untuk kemudian dibimbing oleh guru bagaimana menerapkan apa yang dipelajari dan pentingnya mempelajari sesuatu. Pembelajaran dimulai dengan sajian atau tanya jawab lisan (ramah, terbuka, negosiasi) yang terkait dengan dunia nyata kehidupan peserta didik(daily life modeling), sehingga akan terasa manfaat dari materi yang akan disajikan, motivasi belajar muncul, dunia pikiran peserta didik menjadi konkret, dan suasana menjadi menyenangkan.

Sanjaya (2006: 253), bahwa pendekatan kontekstual atau Contextual Teaching and Learning (CTL) adalah suatu strategi pembelajaran yang menekankan pada proses keterlibatan peserta didik secara penuh untuk dapat menemukan materi yang dipelajari dan menghubungkannya dengan situasi kehidupan nyata, sehingga mendorong peserta didik untuk dapat menerapkannya dalam kehidupan mereka.

Dari pernyataan diatas, berarti bahwa dengan pendekatan kontekstual, peserta didik diberikan kesempatan secara penuh untuk mengkonstruksi pengetahuan yang telah diperoleh dari hasil pengalamannya ke dalam proses menemukan suatu konsep, sehingga peserta didik merasa bahwa materi yang telah diperoleh dari pengalamannya masih berguna dan dapat membantu pemahamannya terhadap pembelajaran yang berlangsung. Dari hubungan kehadiran situasi

kehidupan nyata dalam pembelajaran dengan menggunakan pendekatan kontekstual inilah diharapkan dapat memunculkan dan meningkatkan kemampuan koneksi matematis baik itu yang berkaitan dengan antarkonsep matematika maupun matematika dengan kehidupan seharihari.Dari pemberian masalah yang tidak rutin juga diharapkan kemampuan matematis dapat meningkat, sebagaimana bahwa permasalahan yang diberikan kepada peserta didik bukanlah soal yang biasa ditemuinya, melainkan terdapat tantangan dalam memilih dan menyusun strategi pemecahan masalah.Hasil penelitian Northwest Regional Education Laboratories (Depdiknas, 
2002) melaporkan bahwa pengajaran kontekstual dapat menciptakan kebermaknaan pengalaman belajar dan meningkatkan prestasi akademik peserta didik.

Demikian pula Owens (2001) menyatakan bahwa pengajaran konteksual secara praktis menjanjikan peningkatan minat (ketertarikan) belajar peserta didik dari berbagai latar belakang serta meningkatkan partisipasi peserta didik dengan mendorong secara aktif dalam memberikan kesempatan kepada mereka untuk mengkonstruksi pengetahuan dan mengaplikasikan pengetahuan yang telah mereka peroleh sehingga dapat meningkatkan pemecahan masalah matematis di kehidupan sehari-hari.

Kelebihan dalam pembelajaran kontekstual (Anisa 2009), diantaranya: a). Pembelajaran lebih bermakna, artinya peserta didik memahami materi yang diberikan, dengan melakukan sendiri kegiatan pembelajaran, b) Pembelajaran lebih produktif dan menuntut peserta didik untuk menemukan sendiri, c) Pembelajaran mendorong peserta didik untuk lebih berani mengemukakan pendapat tentang materi yang dipelajari, d). Pembelajaran mendorong rasa ingin tahu peserta didik tentang materi yang dipelajari, e). Pembelajaran menumbuhkan kemampuan peserta didik dalam bekerja sama untuk memecahkan masalah yang diberikan, f). Pembelajaran mengajak peserta didik membuat kesimpulan sendiri dari kegiatan pembelajaran.

Kelemahan dalam pembelajaran kontekstual Dzaki (2009), yaitu: a). Peserta didik yang tidak dapat mengikuti pembelajaran, tidak mendapatkan pengetahuan yang sama dengan teman lainnya karena peserta didik tidak mengalami sendiri, b) Diperlukan waktu yang cukup lama saat proses pembelajaran kontekstual berlangsung, c) Jika guru tidak dapat mengendalikan kelas maka menciptakan situasi kelas yang kurang kondusif, d) Guru lebih intensif dalam membimbing. Karena dengan pendekatan kontekstual guru tidak lagi berperan sebagai pusat informasi. Tugas guru adalah mengelola kelas sebagai sebuah tim yang bekerja bersama untuk menemukan pengetahuan dan ketrampilan yang baru bagi peserta didik, e) Perasaan khawatir pada anggota kelompok akan hilangnya karakteristik peserta didik karena harus menyesuaikan dengan kelompoknya, f) Banyak peserta didik yang tidak senang apabila disuruh bekerjasama dengan yang lainnya, karena peserta didik yang tekun merasa harus bekerja melebihi peserta didik yang lain dalam kelompoknya.Meningkatkan Kemampuan Menghitung Dengan Pendekatan Kontekstual Terhadap Hasil Belajar Peserta Didik Tugasku Sehari-hari Kelas IISD Labschool STKIP Muhammadiyah Sorong

\section{Metode Penelitian}

Penelitian ini merupakan jenis penelitian tindakan kelas (PTK) atau dalam bahasa Inggris disebut Classroom Action Research yang menekankan pada sikap percaya diri dan hasil belajar. PTK terdiri atas rangkaian empat kegiatan utama yang ada pada setiap siklus, yaitu (a) perencanaan, (b) tindakan, (c) pengamatan/pengumpulan data, dan (d) refleksi yang dapat digambarkan sebagai berikut (Arikunto,dkk, 2006:74).

Penelitian ini menggunakan alat pengukur yang disebut tes. Tes kemampuan hasil belajar atau tes prestasi belajar adalah tes untuk mengukur kemampuan yang dicapai seseorang setelah melakukan proses belajar. Sunarti, Selly Rahmawati (2012: 42) mengatakan tes adalah sejumlah 
pertanyaan yang memiliki jawaban benar dan salah.Penelitian ini menggunakan jenis tes tertulis yang berupa soal pilihan ganda untuk siklus I dan uraian untuk siklus II.

(Arikunto, 2006 : 131-132) mengatakan bahwa dalam penelitian tindakan kelas ada dua jenis data yang dapat dikumpulkan peneliti yaitu data kulitatif dan kuantitaitf. Dalam penelitian ini, peneliti menganalisis deskripsi kualitatif melalui lembar observasi dan deskripsi kuantitatif melalui tes hasil belajar.

Berikut rumus penjabarannya: Untuk menganalisis data hasil observasi dilakukan menggunakan skala dengan cara pemberian skor atau rating scale (Sugiyono, 2012: 141-144). Pemberian skor dapat dilihat sebagai berikut : 1 = Kurang, $2=$ Sedang , 3 = Baik, 4 = Sangat Baik Penilaian observasi dilakukan secara klasikal yaitu dengan mencari rata-rata skor yang diperoleh peserta didik dalam setiap item.Jumlah skor maksimum untuk seluruh peserta didik dalam 1 item adalah $25 \times 4=100$ dan skor terendah $25 \times 1=25$.Pembelajaran menggunakan media gambar ini dikatakan berhasil jika skor yang dicapai oleh keseluruhan peserta didik pada masing-masing item sebesar $25 \times 2=50$ atau mempunyai rata-rata sebesar 2 .

Rumusan yang digunakan adalah sebagai berikut:

Keterangan :

$$
\mathrm{M}=\frac{\sum f x}{N}
$$

$\mathrm{M}=$ Skor rata-rata 1 item

$\mathrm{fx}=$ Jumlah skor dalam 1 item

$\mathrm{N}$ = banyaknya peserta didik

Data yang dikumpulkan melalui tes dihitung skor masing-masing dan dari skor ditentukan nilai peserta didik menggunakan rumus sebagai berikut :

$$
\mathrm{P}=\frac{\sum \text { peserta didik yang tuntas belajar }}{\sum \text { peserta didik }} \times 100 \%
$$

Setelah diketahui masing-masing, data dianalisis untuk mencari nilai rata-rata kelas dengan menggunakan rumus sebagai berikut :

$$
\mathrm{Mx}=\frac{\sum x}{N}
$$

\section{Keterangan :}

$\mathrm{Mx}=$ mean

$\Sigma \mathrm{x}=$ jumlah seluruh nilai peserta didik

$\mathrm{N}=$ jumlah peserta didik 


\section{Hasil dan Pembahasan}

Kriteria keberhasilan yang digunakan adalah pedoman kreteria keberhasilan pembelajaran tematik pada kelas II SD Lab. School STKIP Muhammadiyah Sorong.Penelitian ini bertujuan untuk meningkatkan hasil belajar peserta didik pada tema tugasku sehari-hari. Keberhasilannya yaitu jika minimal $75 \%$ peserta didik atau sebesar 6 dari 8peserta didik yang mengikuti proses pembelajaran memperoleh nilai $\mathrm{KKM} \geq 70$. Hal di atas dapat dilihat dari peningkatan hasil belajar peserta didik yaiti nilai rata-rata kelas pada pra siklus sebesar 65,76 kemudian pada siklus I menjadai 71, 92 dan pada siklus II menjadai 79,6. Jumlah peserta didik mampu mencapai KKM 70 pada pra siklus ada 8 peserta didik, pada siklus I ada 8 peserta didik, dan pada siklus II ada 8 peserta didik. Persentase ketuntasan pada pra siklus yaitu $40 \%$, siklus I yaitu $60 \%$ dan siklus II $85,71 \%$. Sehingga pada siklus II sudah lebih mencapai kriteria $75 \%$ peserta didik mencapai KKM 70 dan bagi 1 peserta didik yang belum mencapai KKM akan diserahkan pada guru kelasnya untuk dilakukan remidial. Peserta didik tersebut berinisial XL.

Dari peserta didik tersebut yang belum mencapai KKM dikarenakan termasuk kedalam kelompok peserta didik yang berkemampuan rendah yang cenderung diam, dan kurang aktif dalam kegiatan tanya jawab. Solusi peserta didik tersebut adalah diberikan remidial untuk memperbaiki nilai, Berdasarkan hasil observasi pada pra siklus kemampuan peserta didik masih kurang, hal ini dikarenakan sebagian besar proses pembelajran masih dikuasai oleh guru dan guru belum menggunakan media pembelajran yang ada. Setelah dilakukan tindakan hasilnya mulai ada peningkatan. Pada siklus I kemampuan peserta didik mulai terlihat, meskipun yang aktif sebagian besar adalah peserta didik yang mempunyai keberanian, namun pada siklus II guru merencanakan untuk mengaktifkan peserta didik yang belum berani, dengan memberikan kesempatan untuk bertanya dan menjawab pertanyaan-pertanyaan yang diajukan guru sehingga peserta didik lebih meningkat dan merata. Untuk lebih menghidupkan suasana dan semangat peserta didik guru memberikan motivasi dengan memberikan hadiah pengahargaan kepada peserta didik terbaik.Pada siklus II guru meningkatkan kualitas pewarnaan dan grafis gambar sehingga peserta didik lebih tertarik dalam pembelajaran.

\section{Kesimpulan dan Saran}

Berdasarkan hasil yang telah diperoleh dari siklus I sampai siklus II dapat disimpulkan bahwa dengan penggunaan pendekatan kontekstual dapat meningkatkan hasil belajar tema tugasku sehari-hari peserta didik kelas II SD Lab School STKIP Muhammadiyah Sorong. Penerapan pendekatan kontekstual dalam tema tugasku sehari-hari dapat meningkatkan hasil belajar peserta didik kelas II Labschool STKIP Muhammadiyah Sorong dengan indikator sebagai berikut:

a. Keterampilan guru dalam kemampuan berhitung melalui pendekatakontekstual dapat meningkat dengan kriteria sekurang-kurangnya baik yaitu $22,5 \leq$ skor $<29,5$.

b. Aktivitas peserta didik dalam tema tugasku sehari-hari melalui pendekatan kontekstual meningkat dengan kriteria sekurang-kurangnya baik yaitu $20 \leq$ skor $<25,75$. 
c. Peningkatan kemampuan menghitung menunjukkan ketuntasan belajar individual sebesar $\geq 60$ dengan ketuntasan klasikal sekurang-kurangnya $43 \%$.

\section{Daftar Pustaka}

Anisa (2009).Kelebihan dan Kelemahan Pembelajaran CTL. (Online: 2019)

Arikunto, Suharsimi, dkk. (2006). Prosedur Penelitian Suatu Pendekatan Praktik.Jakarta:Rineka Cipta.

Arikunto, Suharsimi. 2002. Prosedur Penelitian Suatu Pendekatan Praktek.Jakarta : Renika Cipta

Berns, R.G and Erickson, P.M. (2001). Contextual Teaching and Learning. The HighlightZone : Research a Work No. 5 (Online: 2019) tersedia:

Depdiknas.(2002). Kurikulum Tingkat Satuan Pendidikan (KTSP). Jakarta: Depdiknas.

Dzaki (2009).Contextual Teaching and Learning. (Online: Maret 2014) Tersedia:http://arrumsundari.wordpress.com/2012/11/19/contextual-teaching-andlearning/

Owens, T. (2001, Spring). Teacher Preparation for Contextual Teaching andLearning A Statewide Consortium Model.Portland, Oregon; NorthwestRegional Educational Laboratory.

Sanjaya, W. (2006).Strategi pembelajaran berorientasi standar proses pendidikan. Jakarta:Kencana.

Sunarti, Selly Rahmawati. (2014). Penilaian dalam Kurikulum 2013. Yogyakarta: PenerbitANDI. Suryadi, D (2005). Penggunaan Pendekatan Pembelajaran Tidak Langsung sertaPendekatan Gabungan Langsung dan Tidak Langsung dalam RangkaMeningkatkan Kemampuan Berpikir Matematik Tingkat Tinggi Peserta didik SLTP.Disertasi UPI Bandung: Tidak diterbitkan.

Trianto, 2011.Model Pembelajaran Terpadu.Jakarta: Bumi Aksara. 